九州大学学術情報リポジトリ

Kyushu University Institutional Repository

Taxonomic Study of Stenus bicara Naomi and Its Allied Species (Coleoptera : Staphylinidae) from Japan

Naomi, Shun-ichiro

Natural History Museum and Institute

https://doi.org/10.5109/2693

出版情報: ESAKIA. 44，pp. 183-189，2004-03-31. Entomological Laboratory，Faculty of Agriculture, Kyushu University バージョン :

権利関係 : 


\title{
Taxonomic Study of Stenus bicara Naomi and Its Allied Species (Coleoptera: Staphylinidae) from Japan ${ }^{1)}$
}

\author{
Shun-Ichiro NAOMI \\ Natural History Museum and Institute, Chiba 955-2 Aoba-cho, \\ Chuo-ku, Chiba, 260-8682 Japan
}

\begin{abstract}
Stenus bicara Naomi and its allied species are taxonomically studied, and a new species, Stenus yukawai from Shizuoka Prefecture is described. A key for $S$. bicara and its allied species is given for identification.
\end{abstract}

Key words: Coleoptera, Staphylinidae, Steninae, Stenus, new species, Japan.

\section{Introduction}

Stenus bicara, belonging to the subgenus Hypostenus Rey, was described by Naomi (1988) based on the specimens collected from Nikko of Tochigi Prefecture in Honshu. This species is characterized by the following aedeagal conditions: the apico-median part of median lobe simply cuspidate (=mono-cuspidate), the apicolateral corners of median lobe distinct and angulate, the median hooks of internal sac large and almost Cshaped and its anterior ends almost truncate antero-posteriorly, and the parameres with the apico-internal portions wholly membranous and densely setous. After the original description, Stenus bicara has been collected from various parts of Kanto District and also from the southern part of Tohoku District. No distributional records were, however, reported in spite of the fact. Thus, I here recorded the new localities for the species.

At present, known from Japan are two species that are allied to S. bicara, namely, $S$. okamotoi Naomi, 1989 and S. oisami Naomi \& Puthz, 1994, and their taxonomic alliance is based on their common possession of the mono-cuspidate apico-median portion of median lobe, the triangular apical portion of median lobe behind its apico-

1) Studies on the subfamily Steninae from Japan 37. 
lateral corners, etc. In the course of this study I discovered from Shizuoka Prefecture the third species that is allied to S. bicara. As this species is new to science, I described it under the name of Stenus yukawai, and illustrated its taxonomically important structures. In addition, new distributional localities for S. oisami were recorded, and a key for Stenus bicara and its allied three species including the new species, S. yukawai, was also given for identification.

\section{Stenus bicara Naomi}

(Fig.1C)

Stenus bicara Naomi, 1988, Elytra, Tokyo, 16(2):79; Herman, 2001, Bull. Amer. Mus.

Nat. Hist., (265):2081; Puthz \& Naomi, 2003, Newsl. Staphyl. Soc. Jpn., (20):7.

Redescription of aedeagus. Aedeagus with median lobe slender (Fig.1C) or weakly bulbous at base, its apical portion broadly sclerotized, medially with a small but distinct cuspid, with the apical margin between median cuspid and apicolateral corner weakly sinuate, apicolateral corners distinct and weakly angulate; internal sac with median longitudinal bands broad and long, apicolateral bands very thin and short, reaching anteriorly the postero-external corners of median hooks; median hooks large and stout, narrowly fused (Fig.1C) or more or less separated at postero-internal parts, each almost $\mathrm{C}$-shaped, pointed at postero-external part, and almost truncate antero-posteriorly at its anterior end; basal tube large, acutely pointed at posterior end, thick in the middle, and narrowed anteriorly; parameres extending posteriorly beyond the apex of median lobe, each weakly curved externally behind the base of apical broadened part of paramere, apico-internal part of paramere furnished with two long setae and also with dense and shorter setae.

Specimens examined. 3 exs., Mt. Oharashi, Tateiwa Vil., Fukushima Pref., 23. vii. 1996, S. Naomi leg.; 1 ex., Urabandai, Fukushima Pref., 9. vii. 1985, S. Nomura leg.; 5 exs., Iidate Vil., Fukushima Pref., 21. vii. 1985, S. Nomura leg.; 2 paratypes, Chuzenji, Nikko, Tochigi Pref., 28-30. vi. 1982, S. Naomi leg.; 2 exs., same locality, 24. vii. 1985, S. Nomura leg.; 5 exs., Yumoto, Nikko, Tochigi Pref., 25. vii. 1985, S. Nomura leg.; 1 ex., Nikkozawa-Kinunuma, Kuriyama Vil., Tochigi Pref., 3. ix. 1991, S. Naomi leg.; 1 ex., Sawairi, Higashi Vil., Gunma Pref., 22. iv. 2003, N. Kanai leg.; 4 exs., KitamukiJizo, Moroyama, Saitama Pref., 11. x. 1998, S. Arai leg.; 8 exs., Kaisho, Mt. Kiyosumi, Chiba Pref., 19. vii. 1991, S. Naomi leg.; 1 ex., Fudago, Kimitsu C., Chiba Pref., 20. iv. 1989, S. Naomi leg.; 9 exs., same locality, 18. vii. 1991, S. Naomi leg.; 10 exs., Chikura-cho, Chiba Pref., 26. vi. 1994, S. Naomi leg.; 6 exs., Utogi, Futtu C., Chiba Pref., 3. v. 1996, S. Naomi leg.; 3 exs., Mt. Takago, Kimitsu C., Chiba Pref., 5. v. 1996, 


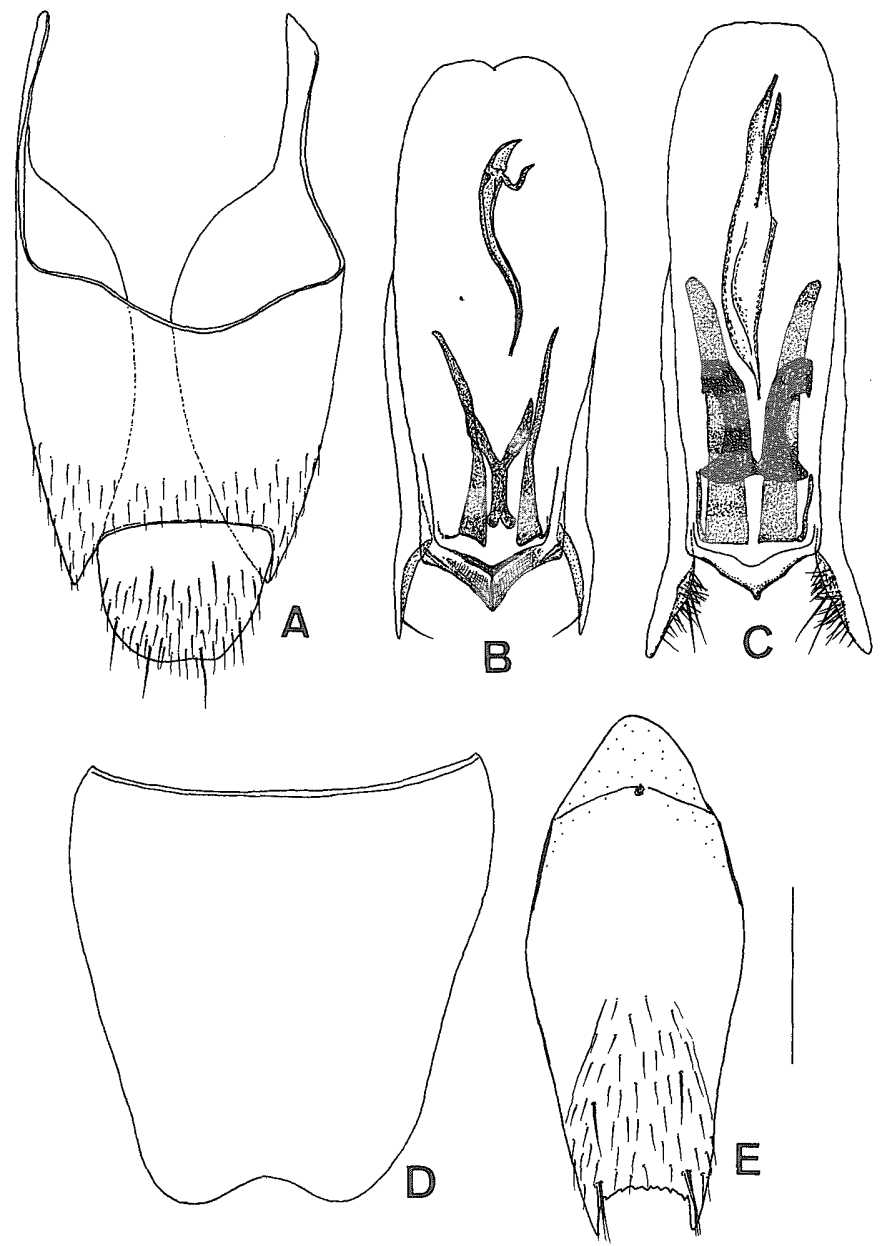

Fig.1. A,B,D,E, Stenus yukawai sp. nov. and C, S. bicara Naomi. A, Ninth and 10th tergites of male in dorsal view; $\mathrm{B}, \mathrm{C}$, aedeagus in ventral view; $\mathrm{D}, 8$ th sternite of male, E, 9th sternite of male. Scale: $0.2 \mathrm{~mm}$.

S. Naomi leg.

Distribution. Japan (Tohoku District: Fukushima Pref.; Kanto District: Tochigi, Gunma, Saitama and Chiba Prefs.).

Remarks. Such aedeagal structures as the apical portion of median lobe, median hooks, median longitudinal bands, etc. are mostly stable for the local populations of Stenus bicara as far as I examined in this study. Slight variations are observed from the specimens from the Boso Peninsula (i.e., those from Futtu City). For example, the anterior end of median hook is more or less narrower than that in the specimens from northern Kanto. The apical margin of median lobe between median cuspid and 
apicolateral corner is smoothly arcuate rather than weakly sinuate, and the apicomedian cuspid of median lobe is more acutely pointed than that in the specimens, for example, from Nikko. However, these are considered infraspecific variation because the intermediate conditions are also found in some specimens from the Boso Peninsula.

\section{Stenus oisami Naomi \& Puthz}

Stenus oisami Naomi \& Puthz, 1994, Jpn. J. Ent., 62(2):304; Herman, 2001, Bull. Amer. Mus. Nat. Hist., (265):2313; Puthz, 2001, Rev. suisse Zool., 108(1):44; Puthz \& Naomi, 2003, Newsl. Staphyl. Soc. Jpn., (20):7.

Specimens examined. 6 exs., Subaru-Line, Mt. Fuji, Yamanashi Pref., 1. viii. 1999, S. Naomi leg.; 7 exs., Azami-Line, Mt. Fuji, Shizuoka Pref., 2. viii. 1999, S. Naomi leg.; 5 exs., Kiyotaki, Mt. Ryogami, Saitama Pref., 10. v. 1997, T. Kishimoto leg.

Distribution. Honshu (Chubu and Kanto Districts)

Remarks. This species was described by Naomi \& Puthz (1994) based on 1 male collected from Mt. Fuji. Puthz (2001) and I (present study) added much specimens from its type locality, and in this paper I also newly recorded this species from Kanto District (Saitama Prefecture). Based on the detailed comparison of the aedeagi of S. oisami with those of S. bicara, it was clarified that the most useful characters for classifying them are gained from the basal tube of internal sac of aedeagus. As there are slight differences between the structure of basal tube in the specimens of Mt. Fuji and that in the specimens of Mt. Ryogami, the structure of basal tube of S. oisami is described as follows: basal tube of internal sac curved or strongly curved at apical part, becoming gradually broader toward the basal part where it is swollen, (and sometimes constricted at the base of the basal swollen part, and broadened again at the most basal portion).

The apical part of median hook is ventrally curved in the holotype of S. oisami as illustrated in Naomi \& Puthz (1994, fig.1E), and this condition was seemed to be useful for separating S. oisami from S. bicara. However, in the specimen of S. oisami from Mt. Ryogami of Saitama Prefecture, such curved condition is not observed. Thus, this character may be useless for their classification when compared with the abovedescribed characters gained from the basal tube of internal sac.

\section{Stenus yukawai Naomi, sp. nov.}

(Fig.1A-B,D-E)

\section{Male.}

Body 3.7-3.8 $\mathrm{mm}$ in length. Head with clypeofrontal area dark red, interocular area 
entirely black and shining; labrum clear reddish brown; maxillary palpi pale yellowish brown to yellowish brown; antennae yellowish brown with apical segments infuscate; pronotum and elytra reddish brown to dark reddish brown, weakly shining; abdomen dark red and shining; legs clear reddish brown.

Relative measurements: HL: 25; HW: 45; PL: 34; PW: 33; EL: 34; EW: 41; SL: 27.

Head with labrum porrect, pubescent, clypeofrontal area punctate and pubescent, basiantennal tubercles elongate, about as long as 1st antennal segment, and placed on the longitudinal depressions of epicranium; interocular area weakly narrowed anteriorly in posterior half and strongly so in anterior half, paired longitudinal depressions being broad in posterior half but obscure in outline in anterior half because of the posterior extention of antennal tubercles, median part between the depressions gently convex; punctures distinct, round, umbilicate and dense, diameter of a large puncture on head about as large as the apical cross-section of 8 th antennal segment; interstices between punctures distinctly microsculptured and shining. Antennae slender, when reflexed extending posteriorly beyond the middle of pronotum, with 3rd to 7 th segments thin, 8 th segment cone-shaped, 9th and 10th segments each almost cone-shaped but distinctly broader than 8th, 11th a little broader than 10th, pointed, with relative lengths of antennal segments from base to apex as: $16: 11: 23: 15: 13: 10: 11: 8: 10: 11: 12$.

Pronotum well convex dorsally, broadest near the middle, weakly rounded in anterior half, weakly constricted at base; surface weakly uneven, with a median longitudinal depression rather vague in outline, the other transverse depression along anterior margin of pronotum shallow and vague; punctures very dense, round to elliptical, and somewhat irregular, diameter of a large puncture about as large as the apical crosssection of 9th antennal segment; interstices between punctures very narrow, microsculptured and shining.

Elytra narrowed at base, uniformly rounded laterally, hind margins together forming a wide and arcuate emargination; surface almost even or weakly uneven, with sutural area feebly elevate; punctures large, very dense, distinct, distinctly larger than those on pronotum, two punctures sometimes put together to form a large one; interstices between punctures very narrow, indistinctly microsculptured and shining.

Legs stout; femora thick; hind tarsi relatively thick, 3rd tarsomere smallest, narrowed at base, 4th tarsomere distinctly bilobed, with relative lengths of tarsomeres from base to apex as $9: 5: 3: 4: 5$.

Abdomen very weakly narrowed posteriorly; punctures on 3rd tergite small, distinct, round, almost regular and moderate in density, interstices between punctures indistinctly microsculptured and shining, narrower than but sometimes a little broader than diameter of a puncture; punctures becoming gradually smaller toward 8th segment; 8th sternite (Fig.1D) with a broad, arcuate and moderately deep emargination at posterior margin; 
9th tergite (Fig.1A) with a pair of basal struts; 9th sternite (Fig.1E) with a pointed and almost straight apicolateral projections, posterior margin between the projections weakly arcuate (Fig.1E) or almost straight, and minutely serrate e; 10th tergite (Fig.1A) entire at posterior part; aedeagus (Fig.1B) with median lobe weakly bulbous in basal half, apical sclerotized portion of median lobe distinctly precipitous, with a median longitudinal keel, apicolateral corners distinct and angulate; internal sac with median longitudinal bands relatively thin, weakly curled in anterior 3/5; median hooks slight, fused in posterior half and then divergent anteriorly to form a Y-shaped structure; basal tube thin, weakly curved and S-shaped, attenuate apically; parameres extending posteriorly a little beyond the apex of median lobe, each with two setae near the base of apical broadened portion, and also with 1 long seta near the apex of apical broadened portion.

Female. Unknown.

Type-series. Holotype: male (Type No., CBM-ZI: 94866), Kanaya, Kanaya-cho, Shizuoka Pref., 13-15. iv. 1994, H. Hayakawa leg. Paratype, 1 male, Arano, Hamaokacho, Shizuoka Pref., 18. vii. 1991, H. Ishikawa leg.

Distribution. Japan (Honshu).

Remarks. Stenus yukawai sp. nov. is allied to S. bicara Naomi and S. oisami Naomi \& Puthz, but is separable from them by the characters used in the key.

Etymology. The specific epithet of this new species is named in honor of Prof. Dr. Junichi Yukawa of Kyushu University.

\section{Key to Stenus bicara and its allied species from Japan}

1(2) Aedeagus with apical sclerotized portion of median lobe less developed; median hooks of internal sac atrophied into small pieces; distribution (Honshu: Chugoku District; Shikoku) ......................................Stenus okamotoi Naomi

2(1) Aedeagus with apical sclerotized portion of median lobe more developed; median hooks of internal sac well-developed, larger and longer.

3(6) Aedeagus with apical sclerotized portion of median lobe gently declivous apically, without a distinct median longitudinal keel; median hooks of internal sac narrowly fused or separated, each hook broader.

4(5) Aedeagus with median hooks of internal sac not curved ventrally at apical parts; basal tube of internal sac almost straight and attenuate apically, thick and stout at the middle, and narrowed toward anterior end (Honshu: Tohoku and Kanto Districts) Stenus bicara Naomi

5(4) Aedeagus with median hooks of internal sac often curved ventrally at apical parts; basal tube of internal sac curved and thin at apical part, becoming gradually 
broader basally, swollen at basal part, (sometimes constricted at the base of the swollen basal part and again broadened at the most basal portion); distribution (Honshu: Chubu and Kanto District) Stenus oisami Naomi \& Puthz 6(3) Aedeagus with apical sclerotized portion of median lobe distinctly precipitous, with a distinct median longitudinal keel; median hooks of internal sac broadly fused in apical half to form Y-shape structure, each hook narrower; distribution (Honshu: Chubu District) Stenus yukawai sp. nov.

\section{Acknowledgements}

I would like to dedicate this paper to Prof. Dr. Junichi Yukawa of Kyushu University at the occasion of his retirement. I thank Dr. V. Puthz (Schlitz, Germany) for his valuable comments on the aedeagal characters of Stenus oisami. I thank Dr. S. Nomura (National Science Museum, Tokyo) and Dr. T. Kishimoto (Japan Wildlife Research Center, Tokyo) for their kind gift or loan of Stenus specimens used for the present study.

\section{References}

Herman, L., H., 2001. Catalog of the Staphylinidae (Insecta: Coleoptera). 1758 to the end of the second millennium. IV. Staphylinine group (Part 1). Bull. Amer. Mus. Nat. Hist., (265): 1807-2440.

Naomi, S.-I., 1988. Studies on the subfamily Steninae (Coleoptera, Oxyporidae) from Japan. IX. Subgenus Hypostenus of the genus Stenus Latreille, Part 1. Elytra, Tokyo, 16(2): 73-84.

Naomi, S.-I., 1989. Studies on the subfamily Steninae (Coleoptera: Oxyporidae) from Japan, X. Subgenus Hypostenus of the genus Stenus Latreille (Part 2). Akitu, New Series, (105): 1-11.

Naomi, S.-I. \& V. Puthz, 1994. Descriptions of four new species of the subgenus Hypostenus of the genus Stenus Latreille (Coleoptera: Staphylinidae) from Japan. Jpn. J. Ent., 62(2): 299-307.

Puthz, V., 2001. Neue japanische Arten der Gattung Stenus Latreille (Coleoptera: Staphylinidae). 266. Beitrag zur Kenntnis der Steninen. Rev. suis. Zool., 108(1): 4155.

Puthz, V. \& S.-I. Naomi, 2003. A list of the Japanese species of subfamily Steninae (Coleoptera, Staphylinidae). Newsl. staphyl. Soc. Jpn., (20): 5-8. (In Japanese.) 
